\title{
Steady increase of lymphogranuloma venereum cases, Czech Republic, 2010 to 2015
}

F Rob ${ }^{1}$, K Jůzlová ${ }^{1}$, H Krutáková ${ }^{2}$, H Zákoucká ${ }^{2}$, D Vaňousová ${ }^{1}$, Z Kružicová ${ }^{1}$, L Machala ${ }^{3}$, D Veselý ${ }^{4}$, D Jilich ${ }^{5}$, J Hercogová ${ }^{1}$

1. Department of Dermatovenerology, Second Faculty of Medicine, Charles University, Na Bulovce Hospital, Prague, Czech Republic

2. National Reference Laboratory for Chlamydia, National Institute of Public Health, Prague, Czech Republic

3. Department of Infectious Diseases, Third Faculty of Medicine, Charles University, Na Bulovce Hospital, Prague, Czech Republic

4. Department of Infectious Diseases, Second Faculty of Medicine, Charles University, Na Bulovce Hospital, Prague, Czech Republic

5. Department of Infectious and Tropical Diseases, First Faculty of Medicine, Charles University, Na Bulovce Hospital, Prague, Czech Republic

Correspondence: Filip Rob (filip.rob@gmail.com)

Citation style for this article:

Rob F, Jůzlová K, Krutáková H, Zákoucká H, Vaňousová D, Kružicová Z, Machala L, Veselý D, Jilich D, Hercogová J. Steady increase of lymphogranuloma venereum cases, Czech Republic, 2010 to 2015. Euro Surveill. 2016;21(11):pii=30165. DOI: http://dx.doi.org/10.2807/1560-7917.ES.2016.21.11.30165

Article submitted on 03 March 2016 / accepted on 17 March 2016 / published on 17 March 2016

Since the notification of the first case of lymphogranuloma venereum (LGV) in the Czech Republic in 2010, the numbers of LGV cases have steadily increased in the country. In 2015, 40 LGV cases were diagnosed, bringing the total for $2010-2015$, to 88 cases. The profile of the most affected group, HIV-positive men who have sex with men with a previous sexually transmitted infection, matches that of those described in LGV outbreaks in western Europe.

In this report we present data on 83 lymphogranuloma venereum (LGV) cases from a total number of $88 \mathrm{LGV}$ cases reported in the Czech Republic between 2010 and 2015 , with 40 cases reported in 2015 alone.

\section{Background}

LGV is a sexually transmitted infection (STI) caused by the $L_{1}, L_{2}$ and $L_{3}$ serovars of Chlamydia trachomatis [1]. Since 2003, LGV has been endemic in western European men who have sex with men (MSM) [1]. Recently, the number of reported cases has been increasing in countries like the United Kingdom (UK), the Netherlands and Spain [2-5]. The first case who presented with typical clinical manifestations compatible with LGV in eastern and central Europe was detected in 2010 in the Czech Republic at the Dermatovenerology department, Na Bulovce Hospital, Prague, in cooperation with the associated AIDS-Centre and the National Reference Laboratory for Chlamydia (NRL) in Prague [6]. Over the last five years, we have noticed an increasing number of patients with LGV in the Czech Republic. Additionally, four cases of LGV in HIV-positive Hungarian men were diagnosed between November 2012 and February 2014 in Hungary [7]. Data from other countries in eastern and central Europe are not publically available.

\section{Study design and population}

The data for this report were collected between February 2010 (when the first case of LGV was detected in the (zech Republic) and December 2015. All the patients described in this report were examined at the Department of Dermatovenerology, Na Bulovce Hospital, Second Medical Faculty, Charles University, Prague, in the Czech Republic. The department is a specialised secondary care centre and annually examines between 2,000 and 2,500 patients for STIs (of these, about a quarter are MSM or men who have sex with women and men (MSWM)). It also cooperates with the Department of Infectious Diseases at Na Bulovce Hospital to provide care for more than 1,200 HIVpositive patients. C. trachomatis nucleic acid amplification tests (NAATs) were performed on all patients with symptoms of urethritis or proctitis, all contacts reported by patients as sexual partners with confirmed chlamydial infection, on all patients with newly diagnosed syphilis, and on patients with a history of risky sexual behaviour (recent unprotected intercourse with unknown partners or foreigners or with multiple partners). This testing scheme was the same throughout the whole period reported here.

\section{Laboratory methods}

Standard validated NAATs for $C$. trachomatis were performed on samples taken from the rectum, urethra, pharynx and ulcers. All rectal samples that tested positive for $C$. trachomatis, as well as urethral and pharyngeal samples in MSM with risky sexual behaviour, were further tested for the LGV genotype in the NRL. The LGV genotype was identified by PCR amplification of a 262 bp fragment of target DNA using the dual-priming oligonucleotide (DPO) Seeplex STI Master Panel 5 test developed by Seegene Inc. (Korea). This method 


\section{FIGURE}

Number of lymphogranuloma venereum cases and Chlamydia trachomatis D-K infections in MSM and MSWM, Na Bulovce Hospital, Prague, Czech Republic, 2010 to $2015(n=83)$

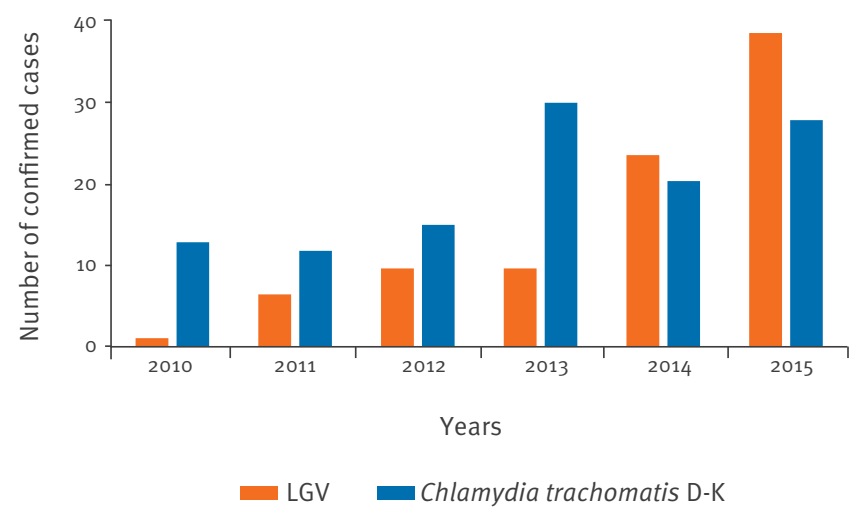

LGV: lymphogranuloma venereum; MSM: men who have sex with men; MSWM: men who have sex with women and men.

targets the $p m p-H$ gene and enables the simultaneous detection of LGV-serovars and the differentiation of L1-3 from other serovars [8].

\section{Data from confirmed cases}

From a total number of 193 MSM and MSWM with a positive $C$. trachomatis test, 83 cases $(43.0 \%)$ were further confirmed to have LGV by our department. While there was only one case of LGV diagnosed in 2010, we diagnosed 35 cases of LGV in 2015. In 2014 and 2015, the number of LGV cases was higher than the number of non-LGV chlamydial infections in MSM and MSWM (Figure).

Of the 83 patients with LGV, 76 (91.6\%) were MSM, whereas only 7 (8.4\%) were MSWM. In total, 70 (84.3\%) of the patients were HIV-positive and 13 (15.7\%) were HIV-negative at the time of diagnosis and in repeated tests three months later. The most common symptoms were rectal infections $72(86.7 \%)$, whereas urethral 7 (8.4\%), pharyngeal $2(2.4 \%)$ and extra genital ulcers 2 $(2.4 \%)$ were rare. In $24(28.9 \%)$ patients the infections were asymptomatic. In six (7.2\%) cases, patients were treated for inflammatory bowel disease (IBD) before the correct diagnosis of LGV was made. Risky sexual behaviour was reported by $64(77.1 \%)$ patients. Co-infections were present in $40(48.2 \%)$ cases, whereas syphilis $22(26.5 \%)$ and gonorrhoea $24(28.9 \%)$ were the most common. Hepatitis C was detected in only one case (Table).

\section{Discussion}

In this report we provide data on LGV diagnoses from one reference centre to understand the trends and epidemiology of this infection in a country in eastern/central Europe. The characteristics of the patients in our centre are very similar to those in the Netherlands and the UK $[3,9]$. The diagnosis of LGV is predominantly in HIV-positive MSM with a previous history of STIs. Given that our centre is the referral centre for the whole country, patients from other parts of the Czech Republic and not only from Prague were diagnosed here. Thus, our data suggest that LGV infection is spreading in the Czech Republic. Only one report from Hungary published in 2015 described four cases of LGV [7]. The lack of data from eastern and central Europe contrasts sharply with the situation in western Europe, where several outbreaks have been reported recently $[2,4]$. This may be due to lower awareness among clinicians in these countries, or less testing and reporting, or less transmission.

The increasing number of LGV cases in the Czech Republic is probably due to several interconnected reasons. LGV is an infection predominantly found in HIV-positive MSM. The number of HIV-positive patients in the Czech Republic has been steadily growing by $10-15 \%$ every year over the last two decades [10]. More than $80 \%$ of these newly diagnosed HIV patients in the Czech Republic are MSM. According to the anecdotal evidence, sexual tourism in the Czech HIV-positive MSM community is also quite widespread. Several patients with confirmed infections in our study reported having had sexual contacts with foreigners from western Europe (Germany, Spain, UK) where LGV outbreaks have been described recently $[1,2,4]$. These imported infections may be further spreading in some subgroups of the local Czech MSM community with high-risk sexual behaviour. This conclusion is supported by the increasing number of gonococcal, non-LGV chlamydial and syphilis cases within this subgroup.

LGV is mandatorily notifiable in the Czech Republic [11]. The very small number of cases notified by other departments may be explained by the low level of awareness among dermatovenerologists, proctologists and urologists in the region. This fact is reflected in the cases with rectal symptoms. These patients were not requested to disclose information about having had receptive anal sex or about having been tested for C. trachomatis infection. Six patients with rectal LGV infection in our group were treated for IBD over the course of several months prior to the correct diagnosis. Four patients received immunosuppressive treatment (azathioprine, systemic corticosteroids), which aggravated their problems. It is therefore also necessary to educate gastroenterologists to check the patient's clinical history for receptive anal intercourse and to perform tests for $C$. trachomatis in men with IBD symptoms [12].

Another problem is the very limited number of laboratories which are able to perform confirmatory tests. In the Czech Republic, this confirmatory test can only be performed by one laboratory (NRL). We are not aware of any other laboratory in the region that does routinely this form of testing. 
TABLE

Confirmed cases of lymphogranuloma venereum by selected characteristics, Na Bulovce Hospital, Prague, Czech Republic, 2010 to 2015 (N=83)

\begin{tabular}{|c|c|}
\hline Characteristics & Number (percentage) \\
\hline Overall number of confirmed cases & $83(100.0 \%)$ \\
\hline \multicolumn{2}{|l|}{ Age group (years) } \\
\hline $15-24$ & $5(6.0 \%)$ \\
\hline $25-34$ & $33(39.8 \%)$ \\
\hline $35-44$ & $35(42.2 \%)$ \\
\hline $45-54$ & $9(10.8 \%)$ \\
\hline $55-64$ & $1(1.2 \%)$ \\
\hline \multicolumn{2}{|l|}{ Sexual orientation } \\
\hline MSM & $76(91.6 \%)$ \\
\hline MSWM & $7(8.4 \%)$ \\
\hline \multicolumn{2}{|l|}{ HIV status } \\
\hline Positive & $70(84.3 \%)$ \\
\hline Negative & $13(15.7 \%)$ \\
\hline \multicolumn{2}{|l|}{ Localisation } \\
\hline Rectum & $72(86.7 \%)$ \\
\hline Urethra & $7(8.4 \%)$ \\
\hline Pharynx & $2(2.4 \%)$ \\
\hline Ulcer in other location & $2(2.4 \%)$ \\
\hline \multicolumn{2}{|l|}{ Symptoms } \\
\hline Yes & $59(71.1 \%)$ \\
\hline No & $24(28.9 \%)$ \\
\hline \multicolumn{2}{|l|}{ Co-infection } \\
\hline Syphilis & $22(26.5 \%)$ \\
\hline Gonorrhea & $24(28.9 \%)$ \\
\hline Chlamydia trachomatis (D-K) & $6(7.2 \%)$ \\
\hline Hepatitis C & $1(1.2 \%)$ \\
\hline \multicolumn{2}{|l|}{ Reinfection } \\
\hline Yes & $7(8.4 \%)$ \\
\hline No & $76(91.6 \%)$ \\
\hline \multicolumn{2}{|c|}{ Clinical history of risky sexual behavioura } \\
\hline Yes & $64(77.1 \%)$ \\
\hline No & $19(22.9 \%)$ \\
\hline
\end{tabular}

MSM: men who have sex with men; MSWM: men who have sex with women and men.

a Recent unprotected intercourse with unknown partners, foreigners or with multiple partners.

The question also remains as to the level of awareness that exists in the other countries of the eastern and central European region because the patients with the LGV infection in our cohort also reported having had sexual contacts with individuals from other countries in the region (Hungary, Poland and Slovakia). It is therefore possible that there is a similar trend in these countries as well.

Nearly half of the patients in our group had another previously undiagnosed sexually transmitted co-infection at the time of the LGV diagnosis. This reinforces the need for testing for HIV, syphilis, hepatitis $C$ and also for gonococcal infections in these patients. In our study, 24 (28.4\%) of the LGV infections were asymptomatic. These asymptomatic LGV cases were only diagnosed through NAATs screening of chlamydial infections in patients with newly diagnosed syphilis. Our department introduced this form of screening in 2009 because of the high number of asymptomatic gonococcal and chlamydial predominantly rectal infections. The percentage of asymptomatic infections in our group was almost identical to a recently published study from the UK [13]. Since nine patients had pharyngeal and urethral LGV, we recommend testing not only rectal samples, but also samples from the urethra and pharynx in high-risk patients. Asymptomatic or undiagnosed patients can quickly spread the infection within the MSM community because of frequent change of sexual partners and because having concurrent relationships are common in some parts of the MSM community $[14,15]$. The early diagnosis of symptomatic patients, tracing the sexual contacts of patients with confirmed LGV, and screening of asymptomatic high-risk patients (HIV-positive MSM with risky sexual behaviour) may help to control the spread of LGV. It is also necessary to educate patients about the risks of the disease, symptoms, protection, and points of contact in case of symptoms.

The main limitation of this report is that we are only presenting data from one centre; however, this is because we are the only centre that systematically focuses on LGV infections in our region. The number of reported asymptomatic LGV cases at our clinic may be higher compared to other centres due to the routine C. trachomatis screening we carry out on patients with newly diagnosed syphilis. We are not able to report the proportion of LGV positive tests from all tests performed for $C$. trachomatis because positive tests in heterosexual patients were not further tested for LGV.

\section{Conclusion}

The increasing number of patients with LGV in our department suggests that the LGV infection is already established and spreading in the Czech Republic and may be present in other countries in the region. Dermatologists, proctologists and gastroenterologists must be more aware of this condition, particularly in patients with rectal symptoms. To keep the situation under control, it is necessary to intensify testing and screening for chlamydial infections and LGV confirmation in eastern and central Europe.

\section{Acknowledgements}

We would like to thank our colleagues from Microbiology, Dermatovenerology, Infectious Diseases departments, $\mathrm{Na}$ Bulovce Hospital and staff from the National Reference Laboratory for Chlamydia who contributed to the management of cases.

\section{Conflict of interest}

None declared. 


\section{Authors' contributions}

FR: prepared the manuscript, collected and analysed data;

$\mathrm{KJ}$ : prepared the manuscript, collected data;

HK: performed LGV genotyping, interpretation of data, critically revised the manuscript;

$\mathrm{HZ}$ : performed LGV genotyping, interpretation of data, critically revised the manuscript;

DVa: critically revised the manuscript, collected and analysed the data;

ZK: collected data, interpretation of data, critically revised the manuscript;

LM: collected data, critically revised the manuscript;

DVe: collected data, critically revised the manuscript;

DJ: collected data, critically revised the manuscript;

$\mathrm{JH}$ : interpretation of data, critically revised the manuscript;

All authors give final approval of the version to be submitted.

\section{References}

1. De Vries HJC. S16. 4 Lymphogranuloma Venereum in Men Who Have Sex with Men. An Ongoing Epidemic Since 10 Years, But Still Not Tackled.Sex Transm Infect. 2013;89(Suppl 1):A24-24. Available from: DOI: 10.1136/sextrans-2013-051184.0076

2. Childs T, Simms I, Alexander S, Eastick K, Hughes G, Field N. Rapid increase in lymphogranuloma venereum in men who have sex with men, United Kingdom, 2003 to September 2015. Euro Surveill. 2015;20(48):30076. Available from: DOI: 10.2807/1560-7917.ES.2015.20.48.30076 PMID: 26675210

3. de Vrieze NHN, van Rooijen M, Schim van der Loeff MF, de Vries HJC. Anorectal and inguinal lymphogranuloma venereum among men who have sex with men in Amsterdam, The Netherlands: trends over time, symptomatology and concurrent infections.Sex Transm Infect. 2013;89(7):548-52. Available from: DOI: 10.1136/sextrans-2012-050915 PMID: 23427272

4. Rodríguez-Domínguez M, Puerta T, Menéndez B, González-Alba JM, Rodríguez C, Hellín T, et al. Clinical and epidemiological characterization of a lymphogranuloma venereum outbreak in Madrid, Spain: co-circulation of two variants. Clin Microbiol Infect. 2014;20(3):219-25. Available from: DOI: 10.1111/14690691.12256 PMID: 23730727

5. Savage EJ, van de Laar MJ, Gallay A, van der Sande M, Hamouda O, Sasse A, et al. European Surveillance of Sexually Transmitted Infections (ESSTI) network. Lymphogranuloma venereum in Europe, 2003-2008. Euro Surveill. 2009;14(48):19428.PMID: 20003898

6. Vanousova D, Zákoucká H, Jilich D, Rozsypal H, Stankova M, Zufanova S, et al. First detection of Chlamydia trachomatis LGV biovar in the Czech Republic, 2010-2011. Euro Surveill. 2012;17(2):20055.PMID: 22264863

7. Balla E, Petrovay F, Mag T, Balázs A, Erdősi T, Együd K, et al. Confirmed cases of lymphogranuloma venereum in Hungary, 2012-2014: supportive diagnostic tool of immunoblotting. Sex Transm Infect. 2015;91(3):200. Available from: DOI: 10.1136/ sextrans-2014-051673 PMID: 25887854

8. Chen $\mathrm{CY}$, Chi KH, Alexander S, Martin IM, Liu H, Ison CA, et al. The molecular diagnosis of lymphogranuloma venereum: evaluation of a real-time multiplex polymerase chain reaction test using rectal and urethral specimens. Sex Transm Dis. 2007;34(7):451-5.PMID: 17075436

9. Rönn M, Hughes G, Simms I, Ison C, Alexander S, White P, et al. Challenges presented by re-emerging sexually transmitted infections: an observational study of lymphogranuloma venereum in the UK. J AIDS Clin Res. 2014;5(8).PMID: 26301124

10. SZU.cz. [Internet]. Roční zprávy o výskytu a šíření HIV/AIDS $v$ ČR [Annual reports on the incidence and spread of HIV / AIDS in the Czech Republic]. [Accessed 16 Mar 2016]. Czech. Available from: http://www.szu.cz/uploads/documents/CeM/ HIV_AIDS/rocni_zpravy/2016/HIV_AIDS_01_2016.pdf
11. Ministry of Health of the Czech Republic. Vyhláška o podmínkách předcházení vzniku a šíření infekční nemocí. [Decree on the prevention and spread of infectious diseases], Pub. L. No. 306/2012. 12 Sept 2012. Czech. Available from: https://portal.gov.cz/app/zakony/zakon.jsp?page $=0 \& n r=306 \sim$ 2F2012\&rpp=15\#seznam

12. Arnold CA, Limketkai BN, Illei PB, Montgomery E, Voltaggio L. Syphilitic and lymphogranuloma venereum (LGV) proctocolitis: clues to a frequently missed diagnosis.Am J Surg Pathol. 2013;37(1):38-46. Available from: DOI: 10.1097/ PAS.ob013e31826a523e PMID: 23095509

13. UK LGV Case-Finding Group,Saxon C, Hughes G, Ison C. Asymptomatic Lymphogranuloma Venereum in Men who Have Sex with Men, United Kingdom. Emerg Infect Dis. 2016;22(1):112-6. Available from: DOI: 10.3201/EID2201.141867 PMID: 26691688

14. Glick SN, Morris M, Foxman B, Aral SO, Manhart LE, Holmes $\mathrm{KK}$, et al. A comparison of sexual behavior patterns among men who have sex with men and heterosexual men and women. J Acquir Immune Defic Syndr. 2012;60(1):83-90. Available from: DOI: 10.1097/QAI.ob013e318247925e PMID: 22522237

15. Elford J, Hart G. If HIV prevention works, why are rates of highrisk sexual behavior increasing among MSM?AIDS Educ Prev. 2003;15(4):294-308.DOI: 10.1521/aeap.15.5.294.23825 PMID: 14516015

\section{License and copyright}

This is an open-access article distributed under the terms of the Creative Commons Attribution (CC BY 4.0) Licence. You may share and adapt the material, but must give appropriate credit to the source, provide a link to the licence, and indicate if changes were made.

This article is copyright of the authors, 2016. 